\title{
GASES AND ELECTROLYTES OF HUMAN FOLLICULAR FLUID
}

\author{
RUTH SHALGI, * P. F. KRAICER AND N. SOFERMAN \\ Department of Zoology, Tel-Aviv University, and \\ Faculty of Continuing Medical Education, Tel-Aviv University, \\ Obstetrical and Gynaecological Department $B$, \\ Municipal-Governmental Medical Centre, Tel-Avio
}

(Received 15th Fanuary 1971, accepted 8th September 1971)

\begin{abstract}
Summary. Samples were obtained from ovarian tissue excised during the second quarter of the menstrual cycle. Sodium, potassium and chloride concentrations resembled those of blood, while $\mathrm{pO}_{2}$ was highly variable, and not correlated with follicular histology. The $\mathrm{pCO}_{2}$ was correlated with $\mathrm{pH}$, but follicular fluid had a more acid $\mathrm{pH}$ than blood plasma. It is concluded that culture media based on 'physiological' saline solutions are appropriate for culture of oocytes.
\end{abstract}

\section{INTRODUCTION}

The results of a study of certain inorganic components of human follicular fluid are compared with media used for the maintenance of oocytes in culture. Analyses of the composition of follicular fluid also provide an indirect test of its origin. Marked differences between it and blood would indicate that the fluid is not a simple transudate of blood.

In order to obtain the maximum of information both on variability and on relationships of the components, it is essential to measure as many as possible in each sample of fluid. Most follicles yielded less than $150 \mu 1$. Determination of $\mathrm{pH}$ required 25 to $40 \mu \mathrm{l}$. The remainder was used to determine gases $\left(\mathrm{CO}_{2}\right.$ and $\mathrm{O}_{2}$ ), sodium, potassium and chlorides. Material for additional analyses was usually not available.

\section{METHODS AND MATERIALS}

The samples of follicular fluid were obtained from excised ovarian tissue. Some attempts were made to collect follicular fluid by puncturing follicles in situ with a syringe and needle, but the samples were almost always visibly contaminated with blood and the application of negative pressure in collecting the fluid changed the composition of the gases.

The following precautions were taken to avoid changes in gas concentrations in the follicular fluid - the tissues were transferred to the laboratory immediately

* Submitted in partial fulfilment of the requirements for the M.Sc. degree in Zoology, Tel-Aviv University. 
after excision; contamination with blood was scrupulously avoided; all collections and transfers were made anaerobically; gas concentrations were determined immediately after removal of the fluid.

A total of forty-three samples of follicular fluid was obtained from nineteen women over a period of 7 months. The women were premenopausal with regular cycles and were to undergo hysterectomy. In women with regular cycles, operation was to take place 8 to 12 days after the onset of the menses; in some women, dating of the cycle was not made due to irregular bleeding. Their ages ranged from 20 to 54, nine of the patients being 40 to 45 years old. In older women, unilateral or bilateral ovariectomy is routinely performed at hysterectomy. These ovaries were the bulk of our material. From the younger women, only small wedge resections were taken, and there was always another, unrelated pathological indication for removal of this tissue, such as endometriosis. Surgery was performed using epidural analgaesia; no supplementary oxygen was given. Epidural analgaesia does not affect blood gas levels (Latterell \& Lundy, 1949; Moir \& Mone, 1964; de Jongh, 1965).

Since most of the patients were approaching menopause, it was necessary to verify the ovulatory capacity of their follicles. Seven women, between the ages of 41 to 51 years, were injected with 7500 to 10,000 i.u. HCG (Pregnyl, Organon) 24 to $36 \mathrm{hr}$ before surgery. The presence of enlarged or ruptured follicles was verified at surgery in all of the patients (cf. Seddon, 1970). Since histological and cytological controls of each follicle from which fluid was obtained were also made, the relatively advanced average age of the patients was not considered a serious detriment.

Between the time of excision and arrival at the laboratory (always less than $5 \mathrm{~min}$ ), the tissue was kept wrapped in saline-moistened gauze to prevent drying and to absorb adherent blood. Follicles were punctured in order of decreasing size, the smallest being approximately $3 \mathrm{~mm}$ in diameter. They were peeled using fine scissors and a corneal forceps until only a thin transparent membrane overlay the fluid. The membrane was punctured with a lancet and the fluid taken up into a glass capillary tube.

When spontaneous filling had stopped, the end of the capillary was inserted into the follicular lumen, and the wall was gently abraded. In the last drops of fluid, many clumps of granulosa cells were found, and usually among them the oocyte in its cumulus. The portion of the tube containing the granulosa cells was broken off, emptied into a small dish, and the cells searched for the oocyte. The clear fluid in the capillary was used for measurements. In the case of large follicles, this was not necessary. The fluid which exuded initially from the punctured follicle was always free of cells. It was taken for analysis whereas the last drops, containing the granulosa cells and the ovum, were collected in a separate tube.

The oocyte was examined by interference contrast microscopy (Allen, David \& Nomarski, 1969) to confirm that it was dictyate. Pieces of the follicular wall were fixed in Bouin's fixative, sectioned and stained with Delafield's haematoxylin and eosin or Azan stain. These two examinations served as criteria for elimination of atretic follicles and cysts.

Gas and $\mathrm{pH}$ measurements were made at $37^{\circ} \mathrm{C}$ using the BMS 3 micro- 
electrode system and the Digital Acid-Base Analyzer, PHM 72 (Radiometer, Copenhagen). Follicular fluid was allowed to flow into the gas-measuring cell (capacity, $100 \mu \mathrm{l}$ ), the $\mathrm{pO}_{2}$ and $\mathrm{pCO}_{2}$ were determined, and the fluid was recovered and stored frozen for electrolyte determinations. Only thirty-six of the forty-three samples were large enough for gas measurements. Sodium and potassium concentrations were measured by flame photometry (Beckman DU) at dilutions of $1: 300$ and $1: 100$. The chloride content of a 20- $\mu 1$ sample was determined in an automatic titrator (Aminco), usually in duplicate. Some samples of follicular fluid were not usable. Hence, the number of samples used for electrolyte determinations was also less than forty-three (Table 1).

TABLE 1

GONGENTRATIONS OF GASES AND ELEGTROLYTES IN HUMAN FOLLIGULAR FLUIDS

\begin{tabular}{|c|c|c|c|c|c|}
\hline Parameter & Units & Mean \pm S.E. & $\begin{array}{l}\text { No. of } \\
\text { samples }\end{array}$ & $95 \%$ fiducial limits* & $\begin{array}{l}\text { Accepted normal values } \\
\text { for human (venous) serum }\end{array}$ \\
\hline $\begin{array}{l}\mathrm{pO}_{2} \\
\mathrm{pCO}_{2} \\
\text { Sodium } \\
\text { Potassium } \\
\text { Chloride } \\
\mathrm{pH}\end{array}$ & $\begin{array}{l}\text { mmHg } \\
\text { mmHg } \\
\text { mequiv./1 } \\
\text { mequiv./1 } \\
\text { mequiv./l }\end{array}$ & $\begin{array}{c}54 \cdot 3 \pm 3 \cdot 54 \\
35 \cdot 1 \pm 1 \cdot 50 \\
124 \pm 3 \cdot 2 \\
4 \cdot 4 \pm 0 \cdot 17 \\
109 \pm 2 \cdot 4 \\
7 \cdot 267 \pm 0.013\end{array}$ & $\begin{array}{l}36 \\
36 \\
37 \\
38 \\
27 \\
33\end{array}$ & $\begin{array}{l}11 \text { to } 97 \\
17 \text { to } 54 \\
84 \text { to } 163 \\
2.4 \text { to } 6 \cdot 5 \\
73 \text { to } 134 \\
7 \cdot 114 \text { to } 7 \cdot 420\end{array}$ & $\begin{array}{l}31 \text { to } 47 \\
39 \text { to } 54 \\
135 \text { to } 155 \\
3 \cdot 6 \text { to } 5 \cdot 5 \\
98 \text { to } 109 \\
7 \cdot 36 \text { to } 7 \cdot 44\end{array}$ \\
\hline
\end{tabular}

* These are the $95 \%$ fiducial limits of the measurements, i.e. $M \pm$ S.D. (' $t$ ' $s \%$ ).

\section{RESULTS AND INTERPRETATIONS}

\section{Electrolytes}

The mean values for all three electrolytes measured were similar to those in blood, although the range of variability was much greater (Table 1). Sodium concentrations tended to be lower than in plasma, twenty-five out of thirty-six values falling below the accepted lower limit for normal plasma ( 135 mequiv./1). The values for all three electrolytes were found to be approximately normally distributed. There was no significant correlation between concentrations of sodium and potassium $(r=0.132)$, sodium and chloride $(r=0.340)$ or potassium and chloride $(\mathrm{r}=-0.256)$.

\section{Oxygen tension}

Oxygen was by far the most variable parameter (Table 1). The statistical variability was not due to scatter; the values were approximately normally distributed. The variation in $\mathrm{pO}_{2}$ was not correlated with any identifiable histological differences in the follicular wall, nor was it related to the size of the follicles. The oxygen concentration in the follicles, therefore, appears to be truly variable over a ninefold range, with the majority of values being higher than those considered normal for venous blood. By analysis of variance, it was shown that the differences in $\mathrm{pO}_{2}$ in follicles of individual patients was as great as the differences between patients $(P>0 \cdot 1$ by the ' $F$ ' test $)$. Thus, the variability of $\mathrm{pO}_{2}$ cannot be attributed to differences in blood oxygen levels between patients. 
Carbon dioxide tension and $p H$

There was a strong negative correlation $(r=-0.733, P<0.001)$ between $\log \mathrm{pCO}_{2}$ and $\mathrm{pH}$. The relationship between them is presented in Text-fig. 1 . Compared to 'normal' human plasma, follicular fluid has a distinctly acid $\mathrm{pH}$ (Table 1). This is best seen by calculating the $\mathrm{pCO}_{2}$ of follicular fluid at $\mathrm{pH}$ $7 \cdot 4$ from the regression line of Text-fig. 1, which gives a value of $21 \mathrm{mmHg}$.

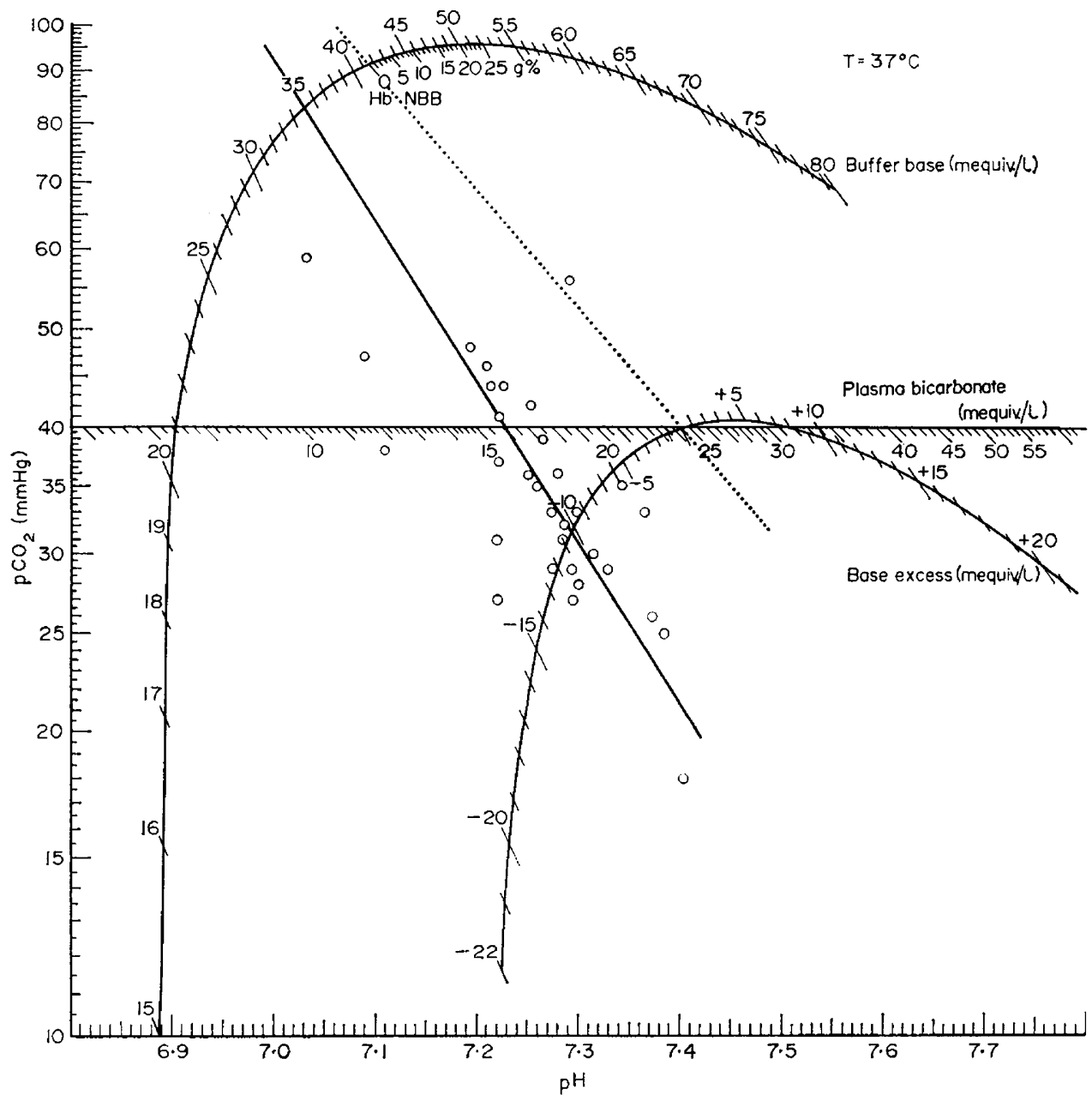

TEXT-FIG. 1. The relationship between carbon dioxide tension and $\mathrm{pH}$ in human follicular fluids. The fitted straight line (product-moment analysis) is $\log \mathrm{pCO}_{2}=13 \cdot 184-1.6025$ $\mathrm{pH}$; the dotted line represents the ideal line for 'normal' plasma (Siggaard-Andersen, 1963).

Using the Siggaard-Andersen (1963) Alignment Nomogram, the Base Excess of all follicular fluids for which $\mathrm{pCO}_{2}$ and $\mathrm{pH}$ values were available were evaluated. Except for one value $\left(\mathrm{pH}=7 \cdot 291, \mathrm{pCO}_{2}=56 \mathrm{mmHg}\right.$, Base Excess $=+1$ ), all the rest lay between -6 and -15 , the mean \pm S.E. being $-10 \cdot 1 \pm 0 \cdot 39$ mequiv./l. In other words, although $\mathrm{pCO}_{2}$ is a major determinant of the $\mathrm{pH}$ 
of follicular fluid, the fluid must also contain a comparatively large excess of non-volatile acid.

The concentration of oxygen in the follicular fluid reflects the rate at which oxygen diffuses into the follicles from the blood minus the rate of its utilization in the follicle. A strong negative correlation would be expected between the $\mathrm{pO}_{2}$ and the $\mathrm{pCO}_{2}$, but was not found $(\mathrm{r}=-0.054)$. The $\mathrm{pO}_{2}$ also had greater variability (coefficient of variation $=39 \%$ ) than $\mathrm{pCO}_{2}(25 \%)$. The lack of any apparent relationship between $\mathrm{pCO}_{2}$ and $\mathrm{pO}_{2}$ suggests that the level of $\mathrm{CO}_{2}$ in the follicle is regulated by processes other than free diffusion of gases.

\section{DISGUSSION}

There is no direct contact between the liquor folliculi and the vasculature. Blood vessels do not penetrate beyond the theca interna. Between the liquor and the blood vessels, there are two structures - the membrana propria and the membrana granulosa. Blood filtrate must pass both. The permeability of the barrier separating the blood plasma from the liquor folliculi has been shown to respond to gonadotrophic stimulus (Zachariae, 1958).

Since there is no direct vascularization of the stratum granulosum, the oocyte in its matrix of cumulus cells can be viewed as an 'in vivo culture', the culture medium being the liquor folliculi. The relevance of our data on gas concentrations to culture of oocytes is apparent. The follicles used were all classed as normal on the basis of the histology of the follicular wall and study of the oocyte. The follicular environment ranged from rich in oxygen to anoxic. The $\mathrm{CO}_{2}$ tension, on the other hand, was quite high, and more constant. Thus, in culture, variations in $\mathrm{O}_{2}$ would presumably be less critical than variations in $\mathrm{CO}_{2}$.

With regard to the electrolyte composition of culture media, the values shown for $\mathrm{Na}, \mathrm{K}$ and $\mathrm{Cl}$ in Table $\mathrm{I}$ are approximately those found in 'physiological' salt solutions. Use of these solutions, as recommended by Edwards, Bavister \& Steptoe (1969) and Brinster (1970), is consistent with our results.

Although follicular fluid resembles blood plasma in many ways, there are certain differences. The major buffers determining the acid-base balance of body fluids are their electrolytes and proteins. Studies in animals indicate similarity between blood and liquor proteins (Caravaglios \& Cilotti, 1957; Shivers, Metz \& Lutwak-Mann, 1964; Desjardins, Kirton \& Hafs, 1966). We have unpublished results indicating that the same is true in women. The similarity of the composition of the liquor and plasma-both proteins and major electrolytes - suggests that the regulation of the acid-base balance is similar in both, but that liquor folliculi has an acid excess of approximately 10 mequiv./l.

The results of this study provide no basis for an explanation of the low $\mathrm{pH}$ of follicular fluid. Bovine follicular fluid is rich in acid mucopolysaccharides (Zachariae \& Jensen, 1958) and, if these are also present in the human, they may explain the negative base excess. More detailed analysis of this question is being undertaken.

\section{REFERENGES}

Allen, R. D., David, G. B. \& Nomarski, G. (1969) The Zeiss-Nomarski differential interference equipment for transmitted-light microscopy. Z. wiss. Mikr. 69, 193. 
BRINSTER, R. L. (1970) In vitro cultivation of mammalian ova. In: Advances in the Biosciences, Vol. 4, p. 199. Ed. G. Raspé. Pergamon Press, Oxford.

Caravaglios, R. \& Cilotti, R. J. (1957) A study of the proteins in the follicular fluid of the cow. F. Endocr. 15, 273.

De Jongh, R. H. (1965) Arterial carbon dioxide and oxygen tensions during spinal block. F. Am. med. Ass. 191, 698.

Desjardins, G., Kirton, K. T. \& Hafs, H. D. (1966) Some chemical, immunochemical and electrophoretic properties of bovine follicular fluid. F. Reprod. Fert. 11, 237.

Edwards, R. G., BAvister, B. D. \& Steptoe, P. C. (1969) Early stages of fertilization in vitro of human oocytes matured in vitro. Nature, Lond. 221, 632.

LATTERELL, K. E. \& LunDY, J. S. (1949) Oxygen and carbon dioxide content of arterial blood before and during spinal anaesthesia. Anesthesiology, 10,677.

Morr, D. D. \& MONE, J. G. (1964) Acid-base balance during epidural anaesthesia. Br. F. Anaesth. 36, 480.

SEDDON, R. J. (1970) The ovarian response in women to large single injections of human menopausal gonadotrophin and human chorionic gonadotrophin. F. Reprod. Fert. 23, 299.

Shivers, G. A., Metz, C. B. \& Lutwak-Mann, C. (1964) Some properties of pig follicular fluid. J. Reprod. Fert. 8, 115.

SiggaArd-Andersen, O. (1963) The acid-base status of the blood, 3rd edn. Munksgaard, Copenhagen.

ZACHARIAE, F. (1958) Studies on the mechanism of ovulation: permeability of the blood-liquor barrier. Acta endocr., Copenh. 27, 339.

Zachariae, F. \& Jensen, G. E. (1958) Studies on the mechanism of ovulation. Histochemical and physico-chemical investigations on genuine follicular fluids. Acta endocr., Copenh. 27, 343. 